\title{
気相反応法による炭化チタン微粉体の合成
}

\author{
岡部安三・北条純一・加藤昭夫 \\ (儿州大学 工学部 忍用化学科)
}

ハログン化チタンー炭化ガス-水素系気相反応 $\left(1000^{\circ} \sim 1500^{\circ} \mathrm{C}\right)$ による炭化チタン ( TiC) 微粉体 の合成を行い，その生成条件及び生成物の性質を調べた。

(1) $\mathrm{TiC}$ 粉体生成に対して，八ロダン化チタンは $\mathrm{TiCl}_{4}<\mathrm{TiBr}_{4}<\mathrm{TiI}_{4}$ の順に，炭化ガスは $\mathrm{CCl}_{4} \ll \mathrm{C}_{2} \mathrm{H}_{4}<\mathrm{CH}_{4}$ の順に有効であった。本反応系の生成粉体は, $\mathrm{TiC}_{x}$ と副生炭素からなる.

(2) $\mathrm{TiI}_{4}-\mathrm{CH}_{4}$ 又は $\mathrm{TiI}_{4}-\mathrm{C}_{2} \mathrm{H}_{4}$ 系において, $\mathrm{TiC}$ 粉体収率及び生成物の $\mathrm{TiC}$ 含有率は, $\mathrm{TiI}_{4}$ と炭化水素を $1200^{\circ} \sim 1300^{\circ} \mathrm{C}$ で混合反応させた場合に最高となった． $\mathrm{TiI}_{4}$ と $\mathrm{CH}_{4}$ の濃度を増す と, $\mathrm{TiC}$ 粉体の生成量が増加するが， $\left[\mathrm{CH}_{4}\right] /\left[\mathrm{TiI}_{4}\right]$ の比が高くなると $\mathrm{TiC}$ 粉体生成が抑制され る傾向が見られ, 副生炭素量が増した。

(3) 生成 $\mathrm{TiC}_{x}$ 粉体は, $0.01 \sim 0.2 \mu \mathrm{m}$ の単結晶粒子加らな. $\mathrm{TiC}$ 相の格子定数は 4.307 $4.331 \AA$ 凡゙, 非化学量論組成 $\mathrm{C} / \mathrm{Ti}$ 比 $(x) 0.57 \sim 1.00$ の変化に対応する.

（4）本反忘系での $\mathrm{TiC}$ 粒子は， $\mathrm{TiC}$ の均一核生成とその成長による生成過程をとり，この過 程によって，本実験の結果はよく説明できた.

(1978 年 3 月 20 日受付)

\section{Formation of Fine Titanium Carbide Powders by a Vapor-phase Reaction}

\author{
Yasuzo OKABE, Jun-ichi HOJO and Akio KATO \\ (Department of Applied Chemistry, Faculty of Engineering, Kyushu University, Fukuoka-shi 812)
}

The formation of fine titanium carbide powders by the vapor-phase reaction of the titanium halides-carburizing gases-hydrogen systems was studied between $1000^{\circ} \mathrm{C}$ and $1500^{\circ} \mathrm{C}$ with emphasis on the formation conditions and properties of TiC powders.

(1) For the formation of $\mathrm{TiC}$ powders, the titanium halides were effective as $\mathrm{Ti}$-source in the sequence of $\mathrm{TiCl}_{4}<\mathrm{TiBr}_{4}<\mathrm{TiI}_{4}$ and the carburizing gases as $\mathrm{C}$-source in the sequence of $\mathrm{CCl}_{4} \ll \mathrm{C}_{2} \mathrm{H}_{4}<\mathrm{CH}_{4}$. The powder produced consisted of $\mathrm{TiC}_{x}$ and free carbon.

(2) In the system of $\mathrm{TiI}_{4}-\mathrm{CH}_{4}$ or $\mathrm{TiI}_{4}-\mathrm{C}_{2} \mathrm{H}_{4}$, the yield and content of $\mathrm{TiC}$ powder in the product were high when the mixing temperature of halide and hydrocarbon was $1200^{\circ} \mathrm{C}$ $\sim 1300^{\circ} \mathrm{C}$. The increase in the concentrations of $\mathrm{TiI}_{4}$ and $\mathrm{CH}_{4}$ accelerated $\mathrm{TiC}$ powder formation, but the high $\left[\mathrm{CH}_{4}\right] /\left[\mathrm{TiI}_{4}\right]$ mole ratio suppressed it and increased the amount of free carbon as by-product.

(3) $\mathrm{TiC}_{x}$ powders produced consisted of single-crystalline particles of $0.01 \mu \mathrm{m}$ to $0.2 \mu \mathrm{m}$. The lattice constant of $\mathrm{TiC}_{x}$ was $4.307 \AA$ to $4.331 \AA$ which corresponds to $\mathrm{C} / \mathrm{Ti}$ ratio $(x)$ of 0.57 to 1.00 .

(4) The formation of $\mathrm{TiC}$ particles was concluded to occur by the homogeneous nucleation of $\mathrm{TiC}$ and its growth process. This process could explain the experimental results satisfactorily.

[Received March 20, 1978]

\section{1. 緒言}

超硬耐熱材料として知られる炭化チタンは; 高硬度, 高融点䘮有するほか, 化学的安定性に優れ, 良電導性を 示すなどの特性をもつ. その用途江従来の超硬材料加ら 各種の耐熱材料あるいは電気電子材料へと拉大してい る ${ }^{1)}$.
炭化チタンの各種材料への応用においては, 優れた微 粉体原料を合成することが重要である．炭化チタン粉体 は一般に，金属あるいは金属酸化物と炭素粉末の固相反 忘により合成されている2 ,3)。微粉体合成法としては, 気相反店の利用が活発になっているが，炭化チタンの気 相合成法に関する報告は, コーティングや結晶成長が主 
でせ、5)，微粉体については，プラズマなどを用いた断片 的な報告(6),7があるのみである.

本研究では, 炭化チタン微粉体の気相合成法を開発寸 る目的で，八ログン化チタン $\left(\mathrm{TiCl}_{4}, \mathrm{TiBr}_{4}, \mathrm{TiI}_{4}\right)$-炭 化水素 $\left(\mathrm{CH}_{4}, \mathrm{C}_{2} \mathrm{H}_{4}\right)$ あるいは四塩化炭素 $\left(\mathrm{CCl}_{4}\right)$-水素 系の数種の気相反応による炭化チタン微粉体の合成を行 った，そして，炭化チタン微粉体の生成条件，及び反応 条件が生成粉体の性質に及ぼす影響を明らかにし，炭化 チタン粒子の生成過程について考察した。

\section{2. 実験}

\section{1 原料}

四八ロゲン化チタンは,市販試薬（純度： $\mathrm{TiCl}_{4} 99.99$ $\%, \mathrm{TiBr}_{4} 99 \%$ 以上， $\mathrm{TiI}_{4} 99 \%$ 以上）をその交ま用い た. $\mathrm{CH}_{4}$ 及び $\mathrm{C}_{2} \mathrm{H}_{4}$ は, 活性化銅 $\left(180^{\circ} \sim 200^{\circ} \mathrm{C}\right)$ で脱酸 素し, シリカゲル及びドライアイス・エタノールトラッ プで脱水して使用した。 $\mathrm{CCl}_{4}$ は, 市販品（純度 $99 \%$ 以 上）をそのまま使用した。水素は，活性化銅で脱酸素し たのちにシリカゲル及び液体窒素トラップで脱水して使 用した。

\section{2 気相 合成}

気相反応流通法 (1 気圧) で行った. 反応装置を図 1 亿示寺. $\mathrm{TiCl}_{4}$ (m.p. $-30^{\circ} \mathrm{C}$ ) 壮蒸発器 $\left(50^{\circ} \sim 70^{\circ} \mathrm{C}\right.$ ), $\mathrm{TiBr}_{4}$ (m.p. $39^{\circ} \mathrm{C}$ ) と $\mathrm{TiI}_{4}$ (m.p. $150^{\circ} \mathrm{C}$ ) は蒸発炉 ( そ れぞれ $\left.125^{\circ} \mathrm{C}, 251^{\circ} \mathrm{C}\right)$ で蒸発させ 水素で反応部へ運ん

1) $\mathrm{TiCl}_{4}$-system

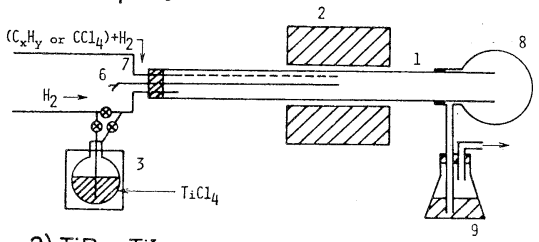

2) $\mathrm{TiBr}_{4}, \mathrm{TiL}_{4}$ - system

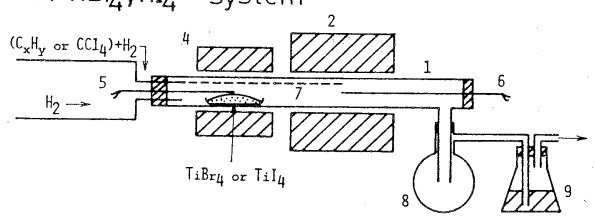

Fig. 1. Reaction apparatus.

1 : Recrystallized alumina tube (i.d. $22 \mathrm{~mm}$ ).

$2: \mathrm{SiC}$ resistance furnace (effective length $20 \mathrm{~cm}$ ).

$3: \mathrm{TiCl}_{4}$ evaporator.

4 : Nichrome heater (used for vaporization of $\mathrm{TiBr}_{4}$ or $\left.\mathrm{TiI}_{4}\right)$.

5 : C.A. thermocouple.

6 : $\mathrm{P} \mathrm{t} / \mathrm{Pt}-\mathrm{Rh}(13 \%)$ thermocouple.

$7:$ Inlet tube for $\left(\mathrm{C}_{x} \mathrm{H}_{y}\right.$ or $\left.\mathrm{CCl}_{4}\right)-\mathrm{H}_{2}$ mixture (mullite tube, i.d. $4 \mathrm{~mm}$ ).

8: Collecting flask (1 1 ).

9 : Collecting bubbler $\left(\mathrm{H}_{2} \mathrm{O}\right)$.
だ。 $\mathrm{CH}_{4}$ あるいは $\mathrm{C}_{2} \mathrm{H}_{4}$ は水素と混合し, $\mathrm{CCl}_{4}$ は蒸発 器中で水素と混合し，それぞれ反応部一導入した。雨反 応ガスは反応管中で混合反応させた，2系統のガスの混 合温度は, 㞸化ガス導入細管の吹き出し口の位置で調節 Lた. 反応温度 (反応炉中央温度) $11000^{\circ} \sim 1500^{\circ} \mathrm{C}$ の 間で変えた. 生成粉体は反応管出口に連結したフラスコ に自然沈降させたのち, 更に排ガスを水中に通して捕集 した。

\section{$2.3 \mathrm{X}$ 線回折及び電子顕微鏡観察}

$\mathrm{X}$ 線回折には $\mathrm{CoK}_{\alpha}$ 線を用い, ケイ素粉末 (100 メ ッシュ）を内部標準として，格子定数（士0.003 $\mathrm{A} ）$ を測 定した: 生成粉体中の $\mathrm{TiC}$ 含有率は, $\mathrm{TiC}(200)$ とケ イ素 (220)の回折線强度比から求めた ( $\pm 5 \%)$. 残りは 遊離炭素*と考えられる。なお；標準炭化チタンには， 市販品 $\left(a_{0}=4.3259 \AA, \mathrm{TiC}_{0.99}\right)$ を用いた.

電子顕微鏡観察用試料は, 試料粉体をエ夕ノール中に 超音波で分散させ，その小滴をメッシュにのせて作製し た. 生成粉体の形状観察には加速電圧 $50 \mathrm{kV}$, 電子線回 折には $200 \mathrm{kV}$ の電子顕微鏡を使用した。

\section{4 八ロゲン化チタンの水素還元}

原料チタン源の反応性の差を調べるために，反応管中 にグラファイト板を置き (中央温度, $1400^{\circ} \mathrm{C}$ ), $\mathrm{TiX}_{4}-\mathrm{H}_{2}$ 系気相からのチタンの析出反応を行った。 反応後, グラ ファイト板を約 $100^{\circ} \mathrm{C}$ 間隔で切断し, 表面上の析出物 をX線回折で調べた。

\section{5 炭化ガスの熱分解}

原料炭素源の反応性を調べるために, $\mathrm{CH}_{4}, \mathrm{C}_{2} \mathrm{H}_{4}$ 及び $\mathrm{CCl}_{4}$ の熱分解を気相合成と類似の条件で行った. $\mathrm{CH}_{4}$ 及び $\mathrm{C}_{2} \mathrm{H}_{4}$ の場合, 分解ガスはガスクロマトグラフィー ( TCD 検出器, 充てん剂; モレキュラーシーブ $5 \mathrm{~A} 60$ 〜80メッシュ及び活性炭60８0メッシュ）を用いて分 析した. $\mathrm{CCl}_{4}$ の場合は, 発生塩化水素を. $1 \mathrm{~N}$ 水酸化子 トリウム水溶液に吸収させ $1 \mathrm{~N}$ 塩酸による逆滴定で定 量した。

\section{3. 結果}

\section{1 炭化チタン粉体の生成}

\section{1 .1 各種チタン源と炭素源との反応性}

表 1 亿, 各 3 種のチタン源及び炭素源の組み合わせに 対する炭化チタン粉体状況ををめた。

炭素源に $\mathrm{CH}_{4}$ を用いた場合, 各チタン源に掠いて, $\mathrm{TiC}$ 粉体の生成が見られた。しがし, チダン源が $\mathrm{TiBr}_{4}$ 及び特に $\mathrm{TiCl}_{4}$ の場合には, $\mathrm{TiC}$ 粉体の生成量は少な く, 反応管内には多量の $\mathrm{TiC}$ のコーティングが析出し た。これらのチタン源の場合, 粉体の生成に注高い $\mathrm{CH}_{4}$

\footnotetext{
* $\mathrm{X}$ 線回折では, $\mathrm{TiC}$ 含有率 $50 \mathrm{wt} \%$ 以下の生成粉体で法 グラファイト (002) の非常にブロードな回折がみられた。 グラファイトは非常に小さい粒子に宗っていることが分る。
} 
Table 1. Formation of TiC powders.

\begin{tabular}{|c|c|c|c|c|}
\hline \multicolumn{2}{|c|}{$\begin{array}{l}\text { Reaction condition }{ }^{\mathrm{a})} \\
\text { and product }{ }^{\mathrm{b})}\end{array}$} & $\mathrm{TiCl}_{4}$ & $\mathrm{TiBr}_{4}$ & $\mathrm{TiI}_{4}$ \\
\hline \multirow{6}{*}{$\mathrm{CH}_{4}$} & $\mathrm{~A}$ & $1200 \sim 1500$ & 1400 & $1100 \sim 1500$ \\
\hline & $\mathrm{B}$ & $8 \sim 48$ & 32 & $2 \sim 24$ \\
\hline & $\mathrm{C}$ & $2 \sim 5$ & 2 & $1 \sim 4$ \\
\hline & $\mathrm{D}$ & $\sim 2$ & $\sim 5$ & $\sim 15$ \\
\hline & $\mathrm{E}$ & $\mathrm{TiC} \leq \mathrm{C}$ & $\mathrm{TiC} \leq \mathrm{C}$ & $\mathrm{TiC}>\mathrm{C}$ \\
\hline & $\mathrm{F}$ & small & small & trace \\
\hline \multirow{6}{*}{$\mathrm{C}_{2} \mathrm{H}_{4}$} & $\mathrm{~A}$ & $1400 \sim 1500$ & & $1000 \sim 1500$ \\
\hline & $\mathrm{B}$ & $12 \sim 15$ & & $2 \sim 4$ \\
\hline & $\mathrm{C}$ & 5 & & 2 \\
\hline & $\mathrm{D}$ & $\sim 0$ & & $\sim 5$ \\
\hline & $E$ & $\mathrm{TiC} \ll \mathrm{C}$ & & $\mathrm{TiC}>\mathrm{C}$ \\
\hline & $\mathrm{F}$ & large & & trace \\
\hline \multirow{6}{*}{$\mathrm{CCl}_{4}$} & A & 1400 & & \\
\hline & $\mathrm{B}$ & 14 & & \\
\hline & $\mathrm{C}$ & 2 & & \\
\hline & $\mathrm{D}$ & 0 & & \\
\hline & $\mathrm{E}$ & only C & & \\
\hline & $F$ & large & & \\
\hline
\end{tabular}

(total gas flow rate $=630 \mathrm{ml} / \mathrm{min}$ )

a) $\mathrm{A}$ : Reaction temperature $\left({ }^{\circ} \mathrm{C}\right)$.

$\mathrm{B}$ : Concentration of carburizing gas $(\%)$.

$\mathrm{C}:$ Concentration of titanium halide (\%).

b) D: Maximum yield of TiC powders based on TiX, supplied (\%).

E : Phase composition of powder produced.

$\mathrm{F}$ : Amount of titanium halide unreacted.

濃度が必要であったため, $\mathrm{CH}_{4}$ の熱分解による炭素粉末 が多量に副生した。これに対して, $\mathrm{TiI}_{4}$ では, $\mathrm{TiC}$ 粉 体收率は最大 $15 \%$ にまで増加し, $\mathrm{CH}_{4}$ 濃度が低下でき たので副生炭素の少ない生成物が得られた。 また, $\mathrm{TiCl}_{4}$ 及び $\mathrm{TiBr}_{4}$ の場合, 未反応八ロゲン化物が生成物中に かなり残存するが， $\mathrm{TiI}_{4}$ の場合は未反応率は $0.1 \%$ 程 度**で非常に小さい。

炭素源に $\mathrm{C}_{2} \mathrm{H}_{4}$ を用いた場合には, $\mathrm{CH}_{4}$ ほど高い $\mathrm{TiC}$

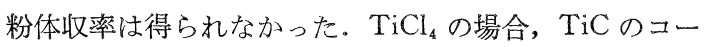
ティングが生成するのみで, 未反応物量が増す。更に, $\mathrm{CCl}_{4}$ を用いた場合には, $\mathrm{TiC}$ 粉体は生成せず, 反応管 内に $\mathrm{TiC}$ のコーティングもほとんどなく, 多量の未反 応物を含む炭素粉末が排出されるのみであった。

\section{1 .2 反応条件の効果}

$\mathrm{TiC}$ 粉体の気相合成には, チタン源として $\mathrm{TiI}_{4}$ が 最も有効であったので, $\mathrm{TiI}_{4}-\mathrm{CH}_{4}$ 系及び $\mathrm{TiI}_{4}-\mathrm{C}_{2} \mathrm{H}_{4}$ 系 について, $\mathrm{TiC}$ 粉体の生成に対する反応条件の効果を 調べた.

\section{(1) 反応温度の効果}

図 2 及び図 3 に，それぞれ $\mathrm{TiI}_{4}-\mathrm{CH}_{4}$ 系及び $\mathrm{TiI}_{4}-$

** $\mathrm{TiI}_{4}$ 末反応量活, 生成物を塩酸で洗浄し, 汇液を水酸化ナ トリウム水溶液で中和して生成する沈殿を加熱分解し $\mathrm{TiO}_{2}$ とする重量法で求めた。
$\mathrm{C}_{2} \mathrm{H}_{4}$ 系で, 反応ガスを反応炉中央で混合した場合（中 央混合法と呼ぶ)の $\mathrm{TiC}$ 粉体収率及び生成粉体中の $\mathrm{TiC}$ 含有率の反応温度による変化を示す. $\mathrm{TiI}_{4}-\mathrm{CH}_{4}$ 系の場 合, $\mathrm{TiC}$ 粉体法 $1100^{\circ} \mathrm{C}$ 付近加生成し, その生成量は 反応温度の上昇とともに大きく増加する. $\mathrm{C}_{2} \mathrm{H}_{4}$ を用い た場合には, $\mathrm{CH}_{4}$ に比べて低温の $1000^{\circ} \mathrm{C}$ から $\mathrm{TiC}$ 粉 体が生成するが, その收率の反応温度の上昇による増加 は小さい。 $\mathrm{TiC}$ 粉体収率は, $\mathrm{TiI}_{4}-\mathrm{CH}_{4}$ 系では $1300^{\circ} \mathrm{C}$ 以上, $\mathrm{TiI}_{4}-\mathrm{C}_{2} \mathrm{H}_{4}$ 系では $1200^{\circ} \mathrm{C}$ 以上で再び低下寸る. 生成粉体中の $\mathrm{TiC}$ 含有率 も同様の温度変化を示し,

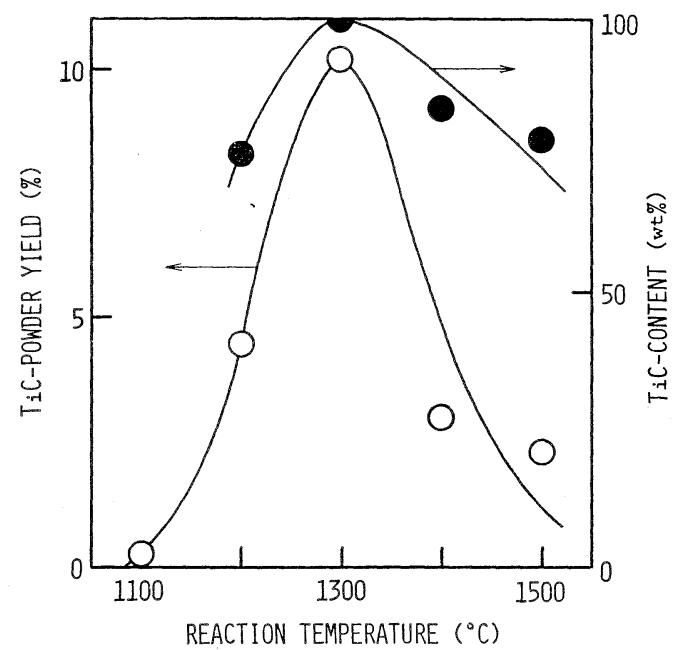

Fig. 2. Variations of the yield and content of $\mathrm{TiC}$ powders with reaction temperature in $\mathrm{TiI}_{4}-$ $\mathrm{CH}_{4}$ system ( $\mathrm{TiI}_{4}$ is mixed with $\mathrm{CH}_{4}$ at the center of furnace).

$\left[\mathrm{CH}_{4}\right]=8 \%,\left[\mathrm{TiI}_{4}\right]=2 \%$, total gas flow rate $=630 \mathrm{ml} / \mathrm{min}$.

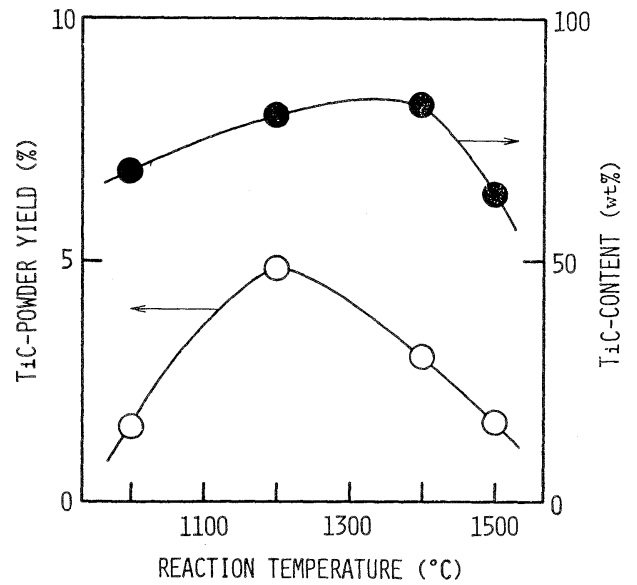

Fig. 3. Variations of the yield and content of $\mathrm{TiC}$ powders with reaction temperature in $\mathrm{TiI}_{4}-$ $\mathrm{C}_{2} \mathrm{H}_{4}$ system ( $\mathrm{TiI}_{4}$ is mixed with $\mathrm{C}_{2} \mathrm{H}_{4}$ at the center of furnace).

$\left[\mathrm{C}_{2} \mathrm{H}_{4}\right]=4 \%,\left[\mathrm{TiI}_{4}\right]=2 \%$, total gas flow rate $=630 \mathrm{ml} / \mathrm{min}$. 


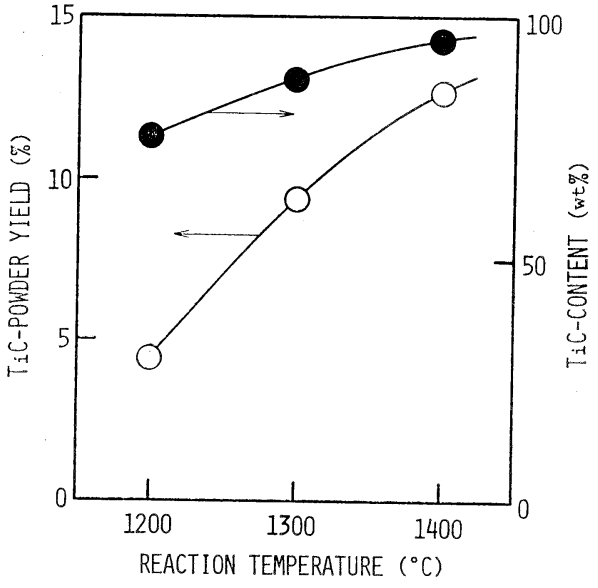

Fig. 4. Variations of the yield and content of TiC powders with reaction temperature in $\mathrm{TiI}_{4}$ $\mathrm{CH}_{4}$ system ( $\mathrm{TiI}_{4}$ is mixed with $\mathrm{CH}_{4}$ at $\left.1200^{\circ} \mathrm{C}\right)$.

$\left[\mathrm{CH}_{4}\right]=8 \%,\left[\mathrm{TiI}_{4}\right]=2 \%$, total gas flow rate $=630 \mathrm{ml} / \mathrm{min}$.

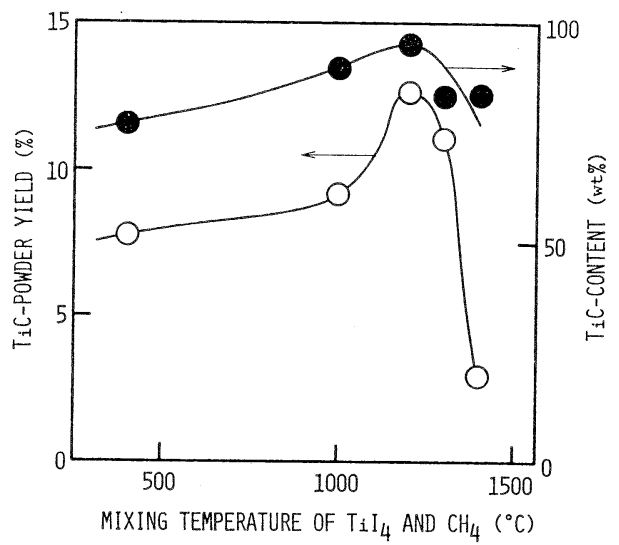

Fig. 5. Dependences of the yield and content of $\mathrm{TiC}$ powders on the mixing temperature of $\mathrm{TiI}_{4}$ and $\mathrm{CH}_{4}$.

$\left[\mathrm{CH}_{4}\right]=8 \%,\left[\mathrm{TiI}_{4}\right]=2 \%$, total gas flow rate $=630 \mathrm{ml} / \mathrm{min}$, reaction temperature $=$ $1400^{\circ} \mathrm{C}$.

$\mathrm{TiI}_{4}-\mathrm{CH}_{4}$ 系では $1300^{\circ} \mathrm{C}$ でほぼ $100 \mathrm{wt} \%$ に達するが， $\mathrm{TiI}_{4}-\mathrm{C}_{2} \mathrm{H}_{4}$ 系では低く 60 80 wt \% である。

図 4 は $\mathrm{TiI}_{4}$ と $\mathrm{CH}_{4}$ の混合温度を $1200^{\circ} \mathrm{C}$ として反 応温度の効果を調べた結果である 反応温度の上昇とと もに, $\mathrm{TiC}$ 粉体収率及び $\mathrm{TiC}$ 含有率は大きく増加する.

\section{（2） $\mathrm{TiI}_{4}$ と炭化水素の混合温度の効果}

反応温度を $1400^{\circ} \mathrm{C}$ とし, $\mathrm{TiI}_{4}$ と $\mathrm{CH}_{4}$ あるいは $\mathrm{C}_{2} \mathrm{H}_{4}$ との混合温度を変化させた場合の結果を図 5 及び図 6 に示寸. $\mathrm{TiI}_{4}-\mathrm{CH}_{4}$ 系の場合, $\mathrm{TiC}$ 粉体収率は, 混合温 度の上昇とともに増加するが， $1200^{\circ} \mathrm{C}$ 以上では再び急 激に減少する。 $\mathrm{TiC}$ 含有率も, 変化は小さいがほぼ同じ 傾向を示す. $\mathrm{TiI}_{4}-\mathrm{C}_{2} \mathrm{H}_{4}$ 系の場合, $\mathrm{TiI}_{4}-\mathrm{CH}_{4}$ 系に比べ

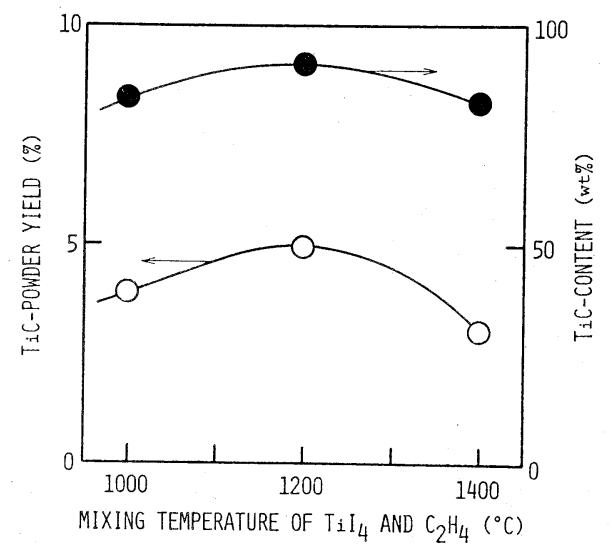

Fig. 6. Dependences of the yield and content of TiC powders on the mixing temperature of $\mathrm{TiI}_{4}$ and $\mathrm{C}_{2} \mathrm{H}_{4}$. $\left[\mathrm{C}_{2} \mathrm{H}_{4}\right]=4 \%,\left[\mathrm{TiI}_{4}\right]=2 \%$, total gas flow rate $=630 \mathrm{ml} / \mathrm{min}$, reaction temperature $=$ $1400^{\circ} \mathrm{C}$.

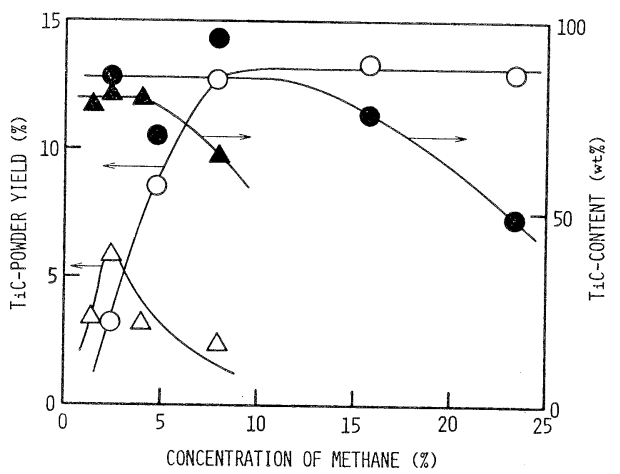

Fig. 7. Variations of the yield and content of $\mathrm{TiC}$ powders with the concentration of methane. $\bigcirc, \quad\left[\mathrm{TiI}_{4}\right]=2 \%, \Delta, \boldsymbol{\Delta}:\left[\mathrm{TiI}_{4}\right]=1 \%$, total gas flow rate $=630 \mathrm{ml} / \mathrm{min}$, reaction temperature $=1400^{\circ} \mathrm{C}$, mixing temperature of $\mathrm{TiI}_{4}$ and $\mathrm{CH}_{4}=1200^{\circ} \mathrm{C}$.

て変化は小さいが同じ傾向が見られる.

\section{(3) 反応ガス濃度の効果}

图 7 k, $\mathrm{CH}_{4}$ 濃度の效果を示す. $\mathrm{TiC}$ 粉体収率は $\mathrm{CH}_{4}$ 濃度の増加とともに大きく増加するが, $\left[\mathrm{TiI}_{4}\right]=2 \%$ のとき $\left[\mathrm{CH}_{4}\right]=8 \%$ 以上では一定となり， $\left[\mathrm{TiI}_{4}\right]=1 \%$ のとき $\left[\mathrm{CH}_{4}\right]=3 \%$ 付近で極大となる. また, $\mathrm{TiI}_{4}$ 濃度 の高い方が $\mathrm{TiC}$ 粉体収率が大きい. 高 $\mathrm{CH}_{4}$ 濃度で $\mathrm{TiC}$ 含有率が減少するのは, $\mathrm{CH}_{4}$ の熱分解による副生炭素が 増加するためである。

\subsection{3 生成炭化チタン粒子の形状と粒径}

$\mathrm{TiI}_{4}-\mathrm{CH}_{4}$ 系及び $\mathrm{TiI}_{4}-\mathrm{C}_{2} \mathrm{H}_{4}$ 系の生成粉体の電子顕微 鏡写真を図 8 に例示する。生成粉体は, 両反応系と夕 $0.01 \sim 0.2 \mu \mathrm{m}$ の粒子から成っている. 粒子の形態に対 しては, 反応温度の効果が大きい. 低温では粒子は球形 で粒径が小さいが, 温度の上昇とともに, 粒子は単結晶 


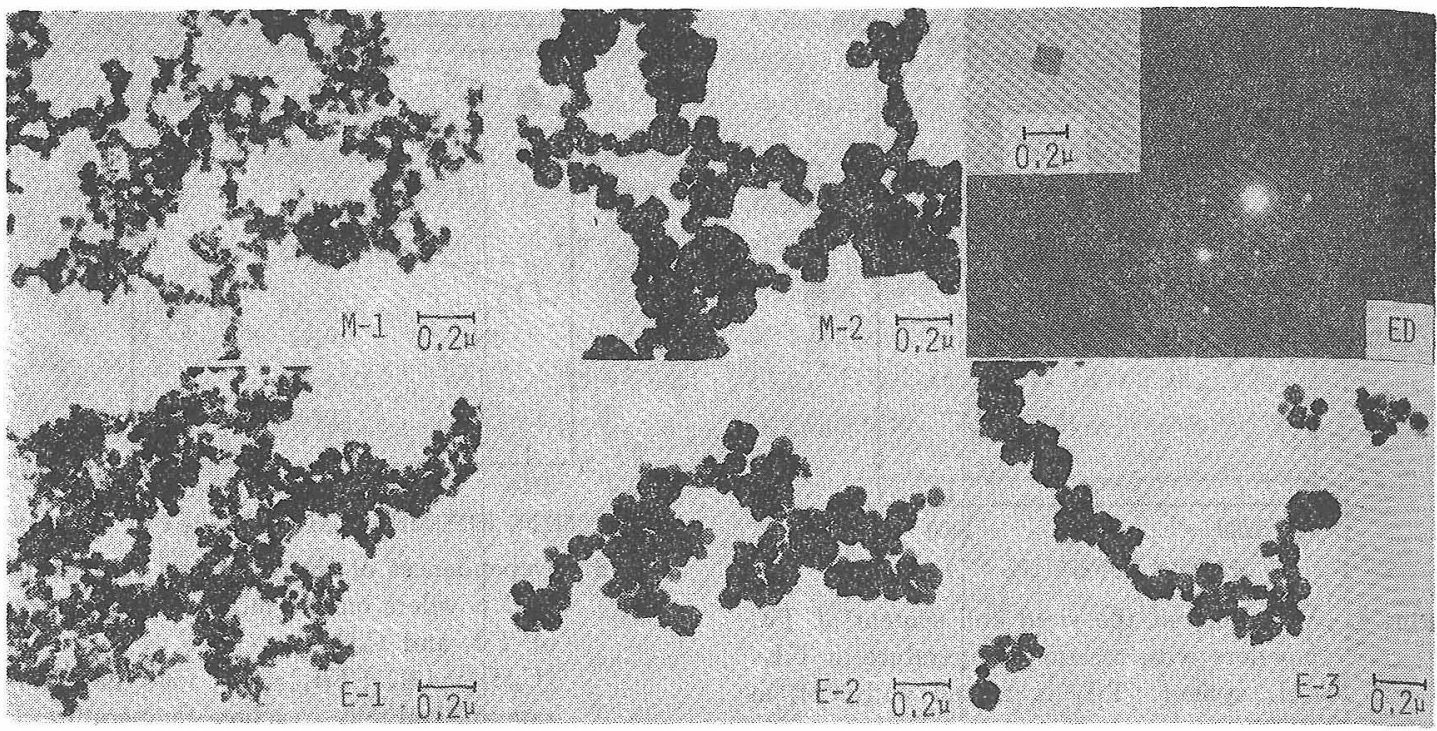

Fig. 8. Electron micrographs of $\mathrm{TiC}$ powders.

Reaction temperature :

M-series : $\mathrm{TiI}_{4}-\mathrm{CH}_{4}$ system (see Fig. 2) $\mathrm{M}-1: 1200^{\circ} \mathrm{C}, \mathrm{M}-2: 1400^{\circ} \mathrm{C}$,

E-series : $\mathrm{TiI}_{4}-\mathrm{C}_{2} \mathrm{H}_{4}$ systern (see Fig. 3) $\mathrm{E}-1: 1000^{\circ} \mathrm{C}, \mathrm{E}-2: 1200^{\circ} \mathrm{C}$,

$\mathrm{E}-3: 1400^{\circ} \mathrm{C}$,

$\mathrm{ED}$ : Electron diffraction pattern of a particle in product of $\mathrm{TiI}_{4}-\mathrm{C}_{2} \mathrm{H}_{4}$ system at $1200^{\circ} \mathrm{C}$ (see Fig. 6).

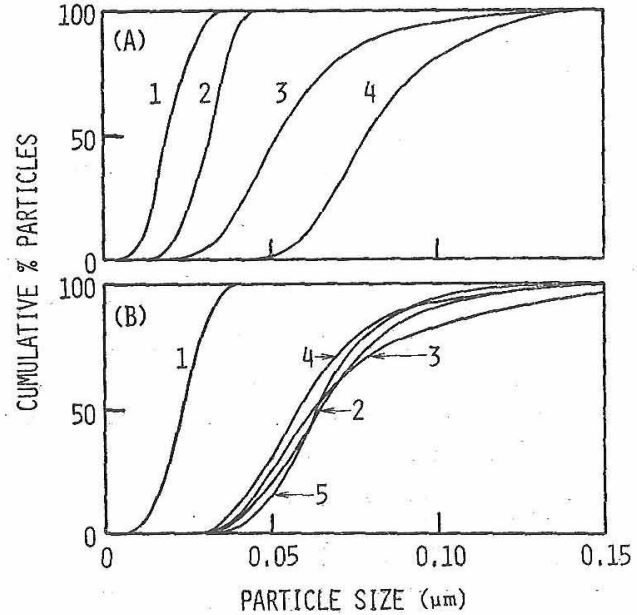

Fig. 9. Effect of reaction temperature on particle size distributions.

Reaction temperature :

(A) : $\mathrm{TiI}_{4}-\mathrm{CH}_{4}$ system (see Fig. 2)

$1: 1200^{\circ} \mathrm{C}, \quad 2: 1300^{\circ} \mathrm{C}, \quad 3: 1400^{\circ} \mathrm{C}$ $4: 1500^{\circ} \mathrm{C}$

(B) : $\mathrm{TiI}_{4}-\mathrm{C}_{2} \mathrm{H}_{4}$ system (see Fig. 3)

$1: 1000^{\circ} \mathrm{C}, \quad 2: 1200^{\circ} \mathrm{C}, \quad 3: 1300^{\circ} \mathrm{C}$, $4: 1400^{\circ} \mathrm{C}, \quad 5: 1500^{\circ} \mathrm{C}$

状の角ばったものとなり大き等精子が多くなる，球状及 び角状の粒子の 11 個について電子線回折を行ったとこ ろ, すい゙て $\mathrm{NaCl}$ 型構造の $\mathrm{TiC}$ の単結晶に対空与る回 折はん点が得られた（図 $8 \mathrm{ED}$ )。また，生成粉体の重量
平均径が $0.05 \mu \mathrm{m}$ 以下の場合, 重量平均径沙 $\mathrm{TiC}(200)$ のX線回折線の半值幅より求めた絬晶子の大きさとほぼ 一致した.このことより，生成した $\mathrm{TiC}$ 粒子注とん ど隼結晶粒子と考光られる。亦㧍, $\mathrm{TiI}_{4}-\mathrm{CH}_{4}, \mathrm{TiI}_{4}-\mathrm{C}_{2} \mathrm{H}_{4}$ 系では炭化水素源度が低く, 後述のよらに，この条件で は炭化水溸の熱分解化よる炭素粉末は生成しない。した 少ってて, 生成粉体中の副生炭素は, $\mathrm{TiC}$ 粒子表面上にコ ーティングとして析出しているものと考えられる.

電子顕幑鏡写真から約 500 個の粒子の粒径を測定し, 図 9 の粒径分布曲線を得艺. $\mathrm{TiI}_{4}-\mathrm{CH}_{4}$ 系の場合, メデ イアン径法 $0.02 \mu \mathrm{m}$ 加ら $0.08 \mu \mathrm{m}$ であり， $1200^{\circ} \mathrm{C}$ か ら $1500^{\circ} \mathrm{C}$ で大さ增加守る. $\mathrm{TiI}_{4}-\mathrm{C}_{2} \mathrm{H}_{4}$ 系で梳，粒径 は $1000^{\circ} \mathrm{C}$ から $1200^{\circ} \mathrm{C}$ 一上昇で增すが，それ以上で 注変化が小さい，粘径分布は，両反応系とも反态温度が 高いほど広がる傾向を示す。

\subsection{4 生成崖化チタン柏の格子定数}

本研究で生成した $\mathrm{TiC}$ 相のX線回折図㹥すべて $\mathrm{NaCl}$ 型搆造のもので离った． $\mathrm{TiI}_{4}$-C $\mathrm{CH}_{4}$ 系及び $\mathrm{TiI}_{4}-\mathrm{C}_{2} \mathrm{H}_{4}$ 系 の $\mathrm{TiC}$ 相の格子定数と反忘温度との関係を 図 10 亿示 す. 格子定数は反応温度の上昇とともに增加する. $\mathrm{TiI}_{4}-$ $\mathrm{C}_{2} \mathrm{H}_{4}$ 系の生成物のほうが， $\mathrm{TiI}_{4}-\mathrm{CH}_{4}$ 系に比べて，同温 度での格子定数が大きい。図 11 は $\mathrm{CH}_{4}$ 濃度の效果を示 したものである。格子定数注 $\mathrm{CH}_{4}$ 濃度の 1 10\% の增 加により急激に增加し，それ以上ではほぼ一定となる。

$\mathrm{TiC}$ 相は, 非化学量諭組成をとり, 格子定数の变化怯 化学組成の变化を示寸。 $\mathrm{TiC}_{x}$ の格子定数 $a_{0}$ は $\mathrm{C} / \mathrm{Ti}$ 比 


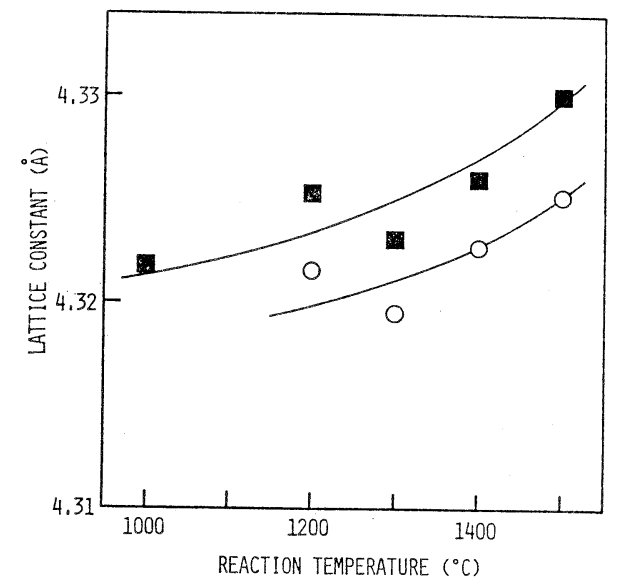

Fig. 10. Dependence of lattice constant of titanium carbide on reaction temperature (products described in Figs. 2 and 3 ).

$\mathrm{O}: \mathrm{TiI}_{4}-\mathrm{CH}_{4}$ system, $\mathrm{TiI}_{4}-\mathrm{C}_{2} \mathrm{H}_{4}$ system

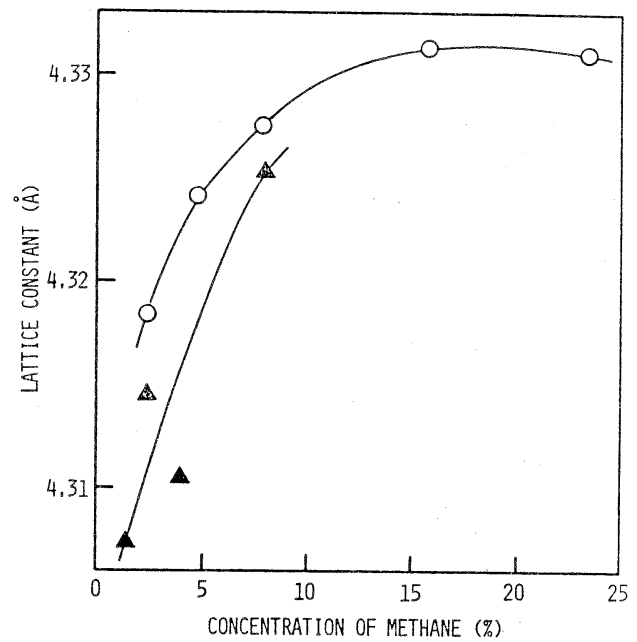

Fig. 11. Dependence of lattice constant of titanium carbide on the concentration of methane (products described in Fig. 7).

$$
O:\left[\mathrm{TiI}_{4}\right]=2 \%, \mathbf{A}:\left[\mathrm{TiI}_{4}\right]=1 \%
$$

(x) によって $4.30 \AA(x=0.5)$ から $4.33 \AA(x=1.0)$ へ増加与る ${ }^{8)}$. 本研究の $\mathrm{TiC}_{x}$ の格子定数 4.307 4.331 は C/Ti 比， $x=0.57 \sim 1.00$ に対応寸る. 反応温度の上 昇及び炭化水素濃度の増加は，生成 $\mathrm{TiC}$ 相の $\mathrm{C} / \mathrm{Ti}$ 比走 化学量論比に向けて增加させることが分る. なお，反応 管内の TiC のコーティングの格子定数は $4.328 \AA$ で $\mathrm{C} / \mathrm{Ti}$ 比 1.00 に対応する. これより, 炭素源の存在下 で熱処理を行らと化学量諭組成となることが分る。

\section{2 ハロゲン化テタンの被遻元性}

$\mathrm{TiX}_{4}(\mathrm{X}=\mathrm{Cl}, \mathrm{I})-\mathrm{H}_{2}$ 系混合妿スをグラフォイト上に 流通したところ，グラファイト上に TiC のコーティン グが生成した。金属チタンのコーティングや粉末生成 は見られなかった。図12に, TiC コーティング量の温

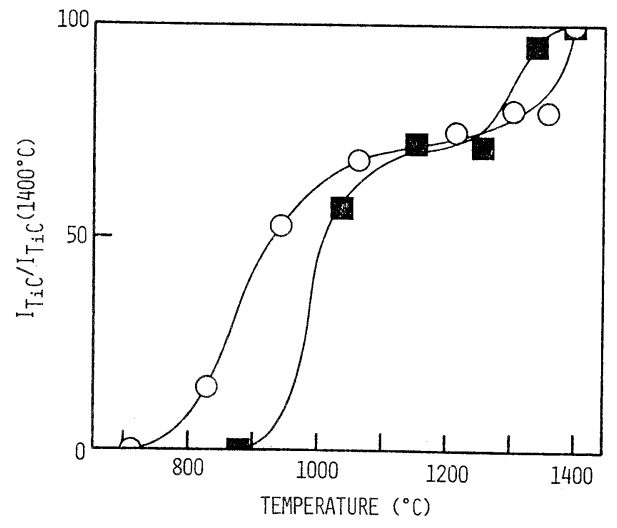

Fig. 12. Formation of TiC-coating on graphite substrate from the vapor phase of $\mathrm{TiX}_{4}-$ $\mathrm{H}_{2}$ system.

$\mathrm{O}: \mathrm{TiI}_{4}-\mathrm{H}_{2}$ system, $: \mathrm{TiCl}_{4}-\mathrm{H}_{2}$ system, $\left[\mathrm{TiX}_{4}\right]=2 \%,\left[\mathrm{H}_{2}\right]=98 \%$, total gas flow rate $=630 \mathrm{ml} / \mathrm{min}$.

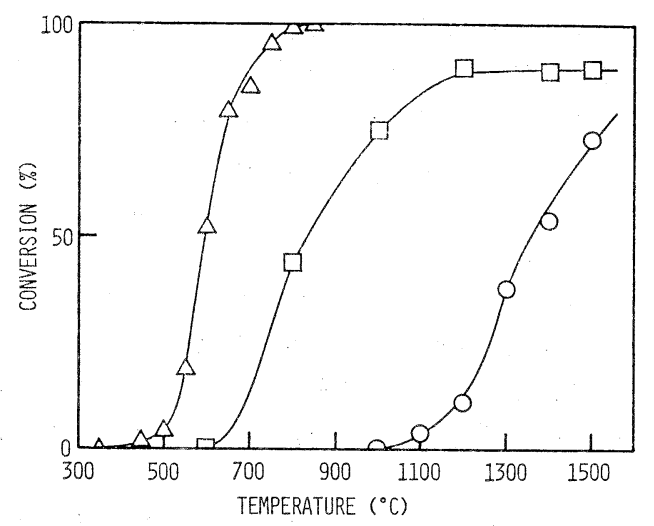

Fig. 13. Pyrolysis of carburizing gas.

$$
\begin{aligned}
& \bigcirc:\left[\mathrm{CH}_{4}\right]=8 \%, \square:\left[\mathrm{C}_{2} \mathrm{H}_{4}\right]=4 \%, \\
& \triangle:\left[\mathrm{CCl}_{4}\right]=4 \%,\left(\text { balance } \mathrm{H}_{2}\right), \\
& \text { total gas flow rate }=620 \mathrm{ml} / \mathrm{min} .
\end{aligned}
$$

度変化老 $\mathrm{X}$ 線回折強度比 $\left(1400^{\circ} \mathrm{C}\right.$ の生成量基準) で 示した. $\mathrm{TiCl}_{4}$ では $900^{\circ} \mathrm{C}, \mathrm{TiI}_{4}$ では $750^{\circ} \mathrm{C}$ から TiC コーティングの生成が開始し, 析出量は温度の上昇とと もに増加する. $\mathrm{TiI}_{4}$ は $\mathrm{TiCl}_{4}$ に比べて析出開始温度が 低く，被還元性が高いことが分る。なお，この実験で は, 多量の未反応八ロゲン化物がガス出口側に排出され t.

\section{3 炭化ガスの熱分解性}

$\mathrm{CH}_{4}, \mathrm{C}_{2} \mathrm{H}_{4}$ 及び $\mathrm{CCl}_{4}$ の分解率と反応温度の関係を図 13 に示吉，熱分解生成物の分析から，各炭化力゙スの分 解反応山次のように起こることが分った。

$$
\begin{aligned}
& \mathrm{CH}_{4} \stackrel{1100^{\circ} \mathrm{C}<}{\longrightarrow} \mathrm{C}\left(+\mathrm{C}_{2} \mathrm{H}_{2}+\mathrm{C}_{2} \mathrm{H}_{4}+\mathrm{C}_{2} \mathrm{H}_{6}\right) \\
& \mathrm{C}_{2} \mathrm{H}_{4} \stackrel{600^{\circ} \mathrm{C}<}{\longrightarrow} \mathrm{C}_{2} \mathrm{H}_{6} \stackrel{800^{\circ} \mathrm{C}<}{\longrightarrow} \mathrm{C}+\mathrm{CH}_{4} \stackrel{1200^{\circ} \mathrm{C}<}{\longrightarrow}(1) \\
& \mathrm{CCl}_{4} \stackrel{400^{\circ} \mathrm{C}<}{\longrightarrow} \mathrm{C}\left(+\mathrm{CH}_{4}+\mathrm{C}_{2} \mathrm{H}_{2}+\mathrm{C}_{2} \mathrm{H}_{4}+\mathrm{C}_{2} \mathrm{H}_{6}\right)
\end{aligned}
$$




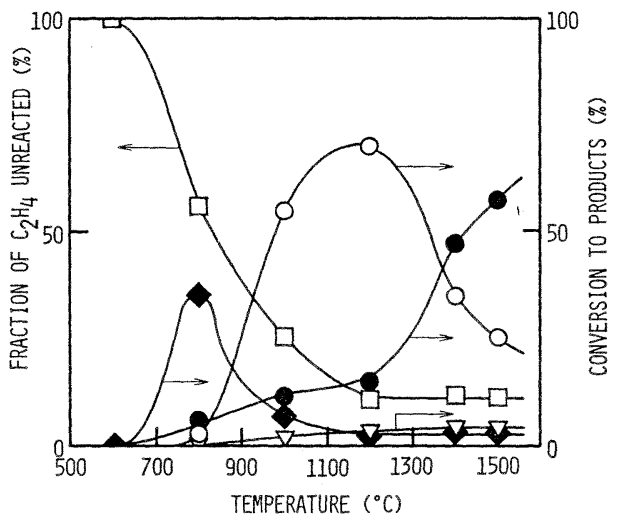

Fig. 14. Hydrocarbons produced in pyrolysis of ethylene.

$\bigcirc: \mathrm{CH}_{4}, \nabla: \mathrm{C}_{2} \mathrm{H}_{2}, \square: \mathrm{C}_{2} \mathrm{H}_{4}, \bullet: \mathrm{C}_{2} \mathrm{H}_{6}$, - graphite, $\left[\mathrm{C}_{2} \mathrm{H}_{4}\right]=4 \%,\left[\mathrm{H}_{2}\right]=96 \%$, total gas flow rate $=620 \mathrm{ml} / \mathrm{min}$.

$\mathrm{CH}_{4}$ の熱分解は $1100^{\circ} \mathrm{C}$ 付近から開始し， $1500^{\circ} \mathrm{C}$ で 分解率は $70 \%$ 以上となる. 分解生成物は大部分グラフ アイトであるが，一部， $\mathrm{C}_{2} \mathrm{H}_{2}, \mathrm{C}_{2} \mathrm{H}_{4}, \mathrm{C}_{2} \mathrm{H}_{6}$ が生成した。 $\mathrm{C}_{2} \mathrm{H}_{4}$ の場合は複雑である. 図 14 亿, $\mathrm{C}_{2} \mathrm{H}_{4}$ の熱分解

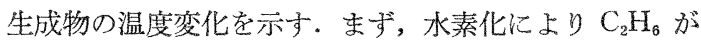
生成するが，その生成量は $800^{\circ} \mathrm{C}$ 付近で最大となり，高 温では再び減少する. $800^{\circ} \mathrm{C}$ 付近から $\mathrm{CH}_{4}$ 及びグラフ アイトが生成し始める. $\mathrm{CH}_{4}$ 生成量は $1200^{\circ} \mathrm{C}$ 付近で最 大となり,より高温で洼熱分解によって再び減少する。

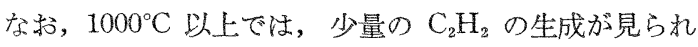
た。

$\mathrm{CCl}_{4}$ は, $\mathrm{CH}_{4}$ 及び $\mathrm{C}_{2} \mathrm{H}_{4}$ に比べて非常に分解しやす く, $400^{\circ} \mathrm{C}$ 以上で熱分解が開始し， $850^{\circ} \mathrm{C}$ で分解率は $100 \%$ 亿達する。分解生成物は, 低温ではタール状物質 及び少量の $\mathrm{CH}_{4}, \mathrm{C}_{2} \mathrm{H}_{2}, \mathrm{C}_{2} \mathrm{H}_{4}, \mathrm{C}_{2} \mathrm{H}_{6}$ であり, 高温では グラファイトであった.

なお,これらの熱分解実験では, 生成グラファイトは

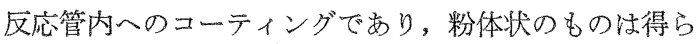
れなかった。

\section{4. 考察}

\section{1 チタン及び炭素源の効果}

気相反応に上る $\mathrm{TiC}$ 粉体の収率注, チタン源につい ては, $\mathrm{TiCl}_{4}<\mathrm{TiBr}_{4}<\mathrm{TiI}_{4}$ の順に増加した. これは, $\mathrm{TiX}_{4}(\mathrm{~g})+\mathrm{CH}_{4}(\mathrm{~g})=\mathrm{TiC}(\mathrm{s})+4 \mathrm{HX}(\mathrm{g})$ の平衡定数の值 $\left(\log K_{\mathrm{p}}(1600 \mathrm{~K}) ; 3.40(\mathrm{X}=\mathrm{Cl}), 2.98(\mathrm{X}=\mathrm{Br})\right.$, $3.30(\mathrm{X}=\mathrm{I}))^{9)}$ の順とは一致せず，平衡論では説明でき ない。 $\mathrm{TiC}$ 粉体収率の增加の序列は, 各八ロゲン化チ夕 ンに扔ける結合エネルギー9)の減少の序列; $\mathrm{TiCl}_{4}$ (103) $>\mathrm{TiBr}_{4}(88)>\mathrm{TiI}_{4}(71)\left(\mathrm{kcal} / \mathrm{mol}, 25^{\circ} \mathrm{C}\right)$ と一致する. このことから， $\mathrm{TiC}$ 粉体の生成は， $\mathrm{TiX}_{4}$ の反応性 ( $\mathrm{Ti}$ -
$\mathrm{X}$ 結合の解離しやすさ) に大きく影響されることが分 る. 実際, 3.2 節で示したように, $\mathrm{TiCl}_{4}$ より $\mathrm{TiI}_{4}$ の 方がグラファイトとの反応性が高い.

一方, 本研究で用いた炭素源については, $\mathrm{TiC}$ 粉体の 収率は $\mathrm{CCl}_{4} \ll \mathrm{C}_{2} \mathrm{H}_{4}<\mathrm{CH}_{4}$ の序列で増加した。 これ \&, $\mathrm{TiCl}_{4}(\mathrm{~g})+(1 / x) \mathrm{C}_{x} \mathrm{H}_{y} \mathrm{Cl}_{z}(\mathrm{~g})+(4 x+z-y) /(2 x)$. $\mathrm{H}_{2}(\mathrm{~g})=\mathrm{TiC}(\mathrm{s})+(4 x+z) / x \cdot \mathrm{HCl}(\mathrm{g})$ の平衡定数の值 $\left(\log K_{\mathrm{p}}(1600 \mathrm{~K}) ; 17.71\left(\mathrm{CCl}_{4}\right), 3.32\left(\mathrm{C}_{2} \mathrm{H}_{4}\right), 3.40\right.$ $\left.\left(\mathrm{CH}_{4}\right)\right)^{9)}$ の順とは一致せず, 平衡論では説明できない. $\mathrm{TiC}$ 粉体收率の増加の序列は, $\mathrm{TiX}_{4}$ の効果とは逆に, これら炭素源の熱安定性（図 13）の増加のそれと一致し ており, 炭素源の熱安定性が $\mathrm{TiC}$ 粉体の生成に大きく 影響することを示している.

以上の $\mathrm{TiC}$ 粉体生成に対するチタン源及び炭素源の 効果から，次のことが結論できる。図 12 のように，八 ロゲン化チタンは $800^{\circ} \sim 900^{\circ} \mathrm{C}$ 以上で初めて反応活性と なる、したがって, TiC 粉体が生成するためには，この 八ロゲン化チタンの反応性が大きくなる高温度域まで炭 素源が安定に存在することが必要である. 更に, 熱安定 性の高い炭素源では, その熱分解による副生炭素の混入 も少なくなる。

\section{2 炭化チタン粒子の生成過程}

本反応系に招いて $\mathrm{TiC}$ 粒子の生成過程は, 次の三つ が考光られる。
(A) $\mathrm{TiX}_{4}(\mathrm{~g}) \stackrel{\mathrm{H}_{2}(\mathrm{~g})}{\longrightarrow} \mathrm{Ti}(\mathrm{s})$
$\mathrm{Ti}(\mathrm{s}) \stackrel{\mathrm{C}_{x} \mathrm{H}_{y}(\mathrm{~g})}{\longrightarrow} \mathrm{TiC}_{x}(\mathrm{~s})$
(B) $\mathrm{C}_{x} \mathrm{H}_{y}(\mathrm{~g}) \rightarrow \mathrm{C}(\mathrm{s})$
$\mathrm{C}(\mathrm{s}) \frac{\mathrm{TiX}_{4}(\mathrm{~g})}{\mathrm{H}_{2}(\mathrm{~g})} \mathrm{TiC}_{x}(\mathrm{~s})$
(C) 均一核生成
$\mathrm{TiX}_{4}(\mathrm{~g})+\mathrm{C}_{x} \mathrm{H}_{y}(\mathrm{~g})+\mathrm{H}_{2}(\mathrm{~g}) \rightarrow \mathrm{TiC}$ (nucleus)
粒成長

$$
\begin{gathered}
\mathrm{TiX}_{n}(\mathrm{ad})+\mathrm{C}_{p} \mathrm{H}_{q}(\mathrm{ad})+\mathrm{H}(\mathrm{ad}) \rightarrow \mathrm{TiC}_{x}(\mathrm{~s}) \\
(n=0 \sim 4) \quad(p=1 \sim 2, q=0 \sim 6)
\end{gathered}
$$

(A) は, $\mathrm{TiX}_{4}$ がまず水素により還元され，金属チタ ン粒子を生成し，それが炭化水素により炭化される過程 である. $\mathrm{WCl}_{6}-\mathrm{CH}_{4}$ 系 ${ }^{10)}, \mathrm{MoCl}_{5}-\mathrm{CH}_{4}$ 系 ${ }^{(1)}$ 気相反応化 よる炭化物生成はこの過程による。これらの反応系で は，塩化物から W あるいは Mo 一の還元反応の平衡 定数が非常に大きい。これに対して， $\mathrm{TiX}_{4}-\mathrm{H}_{2}$ 系では 金属一の還元反応の平衡定数が小さく, 実際, 3.2 節で 述べたように気相での 金属チタン粒子の生成は起こら ず，(A) の過程注否定される.

(B) は, 炭化水素から炭素粉末を生成し，これが $\mathrm{TiX}_{4}$ によりチタン化される過程である。 $\mathrm{TiCl}_{4}-\mathrm{CCl}_{4}$ 系, $\mathrm{TiCl}_{4}-\mathrm{C}_{2} \mathrm{H}_{4}$ 系で炭素粉末注生成するが, $\mathrm{TiC}$ 粉体はほ とんど生成せず，多量の末反応物が排出されたことよ 
り，炭素粉末のチタン化速度はかなり小さいことが分 る. この過程も, 本実験条件下では $\mathrm{TiC}$ 粉体生成への 寄与は小さいと考えられる。

以上より，本反応系での $\mathrm{TiC}$ 粉体の生成過程は，(C) の $\mathrm{TiC}$ の均一核生成とその成長からなると思われる. すなおち，まず気相において $\mathrm{TiC}$ の核が生成し（(8) 式), これがチタン原子及び炭素原子の析出 ((9) 式) により $\mathrm{TiC}_{x}$ 粒子へと成長する***。均一核の生成には, 不均一核の生成に比べて高い過飽和度が必要である。反 応性の低い $\mathrm{TiCl}_{4}, \mathrm{TiBr}_{4}$ で注過飽和度が不足するため に，ほとんど不均一核生成によるコーティングとなる。 反応性の高い $\mathrm{TiI}_{4}$ では, 均一核生成速度が増し, $\mathrm{TiC}$ 粉 体の生成が容易になったものと考えられる，また， $\mathrm{CH}_{4}$ に比べて $\mathrm{C}_{2} \mathrm{H}_{4}$ の方がより低温で $\mathrm{TiC}$ 粉体を生成する のも, $\mathrm{C}_{2} \mathrm{H}_{4}$ の方が低温で高い分解活性を示し, 反応性 が高いためである。

\section{3 反応条件の効果}

\subsection{1 炭化チタン粉体収率}

$\mathrm{TiC}$ 粉体の生成量は，均一核の生成速度に大きく依存 し，その速度はチタン源及び炭素源の反応性の増加及び その濃度の増加により増すと考えられる。

反応温度の上昇による $\mathrm{TiC}$ 粉体収率の増加は（図 2 ４), 図12, 図 13 に示した $\mathrm{TiI}_{4}$ と炭化水素の反応性 の増加と一致する. しかし，炭化水素の熱分解速度が著 しくなる $1300^{\circ} \mathrm{C}$ 以上では，その濃度の低下のために均 一核生成速度が減少し, $\mathrm{TiC}$ 粉体収率が減少する。 $\mathrm{TiI}_{4}$ と炭化水素は，反応管手前で混合して反応部での両ガス の混合状態を良くすることが必要であるが，混合温度が

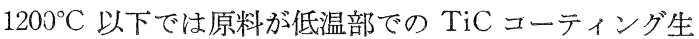
成に消費され $\mathrm{TiC}$ 粉体生成量法減少する.

図 7 の反応ガス濃度の増加による $\mathrm{TiC}$ 粉体収率の増 加は,均一核生成速度が増すことによる。しかし, $\left[\mathrm{TiI}_{4}\right]$ $=1 \%$ の場合には, 高 $\mathrm{CH}_{4}$ 濃度で $\mathrm{TiC}$ 粉体収率がかえ って低下した。 これは, $\mathrm{CH}_{4}$ 濃度の増加により, 粒成 長段階に打いて粒子表面に過剩の炭素が析出し， $\mathrm{TiC}$ 粒 子の成長を阻害するためと考えられる。同様の傾向は， $\mathrm{TiCl}_{4}-\mathrm{CH}_{4}-\mathrm{H}_{2}$ 系気相反応による $\mathrm{TiC}$ ウィスカーの生 成に执いてみられ, $\left[\mathrm{CH}_{4}\right] /\left[\mathrm{TiCl}_{4}\right] \simeq 0.8$ 以上では結晶 成長が阻害される ${ }^{4)}$ 。な㧍， $\left[\mathrm{TiI}_{4}\right]=2 \%$ においては， チタン原子の供給速度が速いために, $\mathrm{CH}_{4}$ 濃度の増加に よる粒成長の抑制効果が顕著にみられない。

\subsection{2 炭化チタン粉体の性質}

反応温度が上昇すると，核生成速度に比べて成長速度 が相対的に増加し，粒径が増加するとともに成長速度の

*** 四八ロゲン化チタン $\left(\mathrm{TiX}_{4}\right)$ は, 高温で水素還元され, 低 級八ロゲン化物 $\left(\mathrm{TiX}_{3}, \mathrm{TiX}_{2}\right)$ を生成すると考えられる が，反応式では気相ハロゲン化チタンを $\mathrm{TiX}_{4}$ で代表し た.
異方性のために粒子は角ばってくる。 $\mathrm{TiI}_{4}-\mathrm{C}_{2} \mathrm{H}_{4}$ 系の場 合, $\mathrm{C}_{2} \mathrm{H}_{4}$ が $\mathrm{CH}_{4}$ に比べて低温活性なために $\mathrm{TiC}$ 粒子の 成長速度が速く, $1300^{\circ} \mathrm{C}$ 以下の低温域で $\mathrm{TiI}_{4}-\mathrm{CH}_{4}$ 系よ り大きな粒子が生成する。しかし， $\mathrm{TiI}_{4}-\mathrm{C}_{2} \mathrm{H}_{4}$ 系 $1200^{\circ} \mathrm{C}$ 以上では,熱分解による炭素源濃度の低下が, 反応温度の 上昇による成長速度の増加を抑え，粒径は一定となる。

反応温度の上昇及び炭化水素濃度の増加により, 炭素 の供給速度が増し, 生成 $\mathrm{TiC}$ 相の $\mathrm{C} / \mathrm{Ti}$ 比が増加する. $\mathrm{TiI}_{4}-\mathrm{C}_{2} \mathrm{H}_{4}$ 系の方が, $\mathrm{TiI}_{4}-\mathrm{CH}_{4}$ 系に比べて格子定数が 大きいのは, $\mathrm{C}_{2} \mathrm{H}_{4}$ が $\mathrm{CH}_{4}$ に比べて反応性が高いことに よる.

\section{5. 結論}

（1）八ロゲン化チタン-炭化ガス-水素系の気相反応 による $\mathrm{TiC}$ 粉体の生成注対して，八ロゲン化チタンは, $\mathrm{TiCl}_{4}<\mathrm{TiBr}_{4}<\mathrm{TiI}_{4}$ の順に, 炭化ガスは, $\mathrm{CCl}_{4} \ll$ $\mathrm{C}_{2} \mathrm{H}_{4}<\mathrm{CH}_{4}$ の順に有効であった。原料 $\mathrm{TiX}_{4}$ に対する $\mathrm{TiC}$ 粉体收率の最大は, $\mathrm{TiI}_{4}-\mathrm{CH}_{4}$ 系での 15\% であ り，炭素含有率の少ない $\mathrm{TiC}_{\boldsymbol{x}}$ 粉体が得られた。

(2) $\mathrm{TiC}_{x}$ 粉体の粒径は $0.01 \sim 0.2 \mu \mathrm{m}$, 格子定数 は 4.307 4.331 ̊ ( $\mathrm{C} / \mathrm{Ti}$ 比, $x=0.57 \sim 1.00)$ であり, 反応条件により粒径及び $\mathrm{C} / \mathrm{Ti}$ 比が制御されることが分 った。

（3）本反応系に打ける $\mathrm{TiC}$ 粒子生成過程は， $\mathrm{TiC} の$ 均一核生成とその成長からなる。 $\mathrm{TiC}$ 粉体の生成には, 八ログン化チタン及び炭化ガスの反応性の増大する温度 域が一致することが重要である.

（4）炭化チタン粉体の合成には, チタン源として $\mathrm{TiI}_{4}$ が有効であるが，本実験条件下で得られた $\mathrm{TiC}$ 粉 体収率は低く， $\mathrm{TiI}_{4}$ の多くは $\mathrm{TiC}$ コーティング析出に 消費される。 $\mathrm{TiI}_{4}$ は高価であり，工業的には安価な $\mathrm{TiCl}_{4}$ を使用することが望まれる。 $\mathrm{TiC}$ 粉体の低い収率 は, 主に八ロゲン化チタンの反応性が低いことに起因し ている. 反応速度の増加には温度の上昇が最も効果的で 亦るので，プラズマの利用が有効であろう ${ }^{6)}$. 比較的低 温での気相反応によって $\mathrm{TiC}$ 粉体の收率を高める方法 として, 特許》報告されているように, $\mathrm{WCl}_{6}, \mathrm{MoCl}_{5}$ などの核発生凰を反灾系に 少量添加することによって, $\mathrm{TiC}$ の均一核生成を促進させることが考光られる。ま た, 反応器壁に不活性ガスを流し、コーティングの析出 を抑えることも粉体収率の向上に有効であるう。

謝辞電子線回折は江口鉄男教授の研究室で行った。 また, 本研究の経費の一部は大倉和親記念研究助成金 (1976) 及 び文部省科学研究費 (No. 275429, 1977) によった. 記して謝意 を表する。

\section{文献}

1) L.E. Toth, "Transition Metal Carbides and Nitrides" (J.L. Margrave, ed. "Refractory Materials" Vol. 7), 
Academic Press, New York and London (1971) p. 128.

2) 武井 武, 河嶋千壯, “新しい工業材料の科学 A-7, 超硬 耐熱材料”，金原出版（1967） p. 1-31.

3) 榛葉久吉, “粉末治金学”, コロ十社 (1975) p. 100-35.

4) A. Kato, M. Yasunaga and N. Tamari, J. Cryst. Growth, 37, 293-300 (1977).

5) J.J. Nickl, M. Reichle and R. Vesper, in ! Proc. 3rd Intern. Conf, on Chemical Vapor Deposition (Salt Lake City, 1972) p. 369-82.

6) E. Neuenschwander, J. Less-Common Metals, 11,
365-75 (1966).

7) K.A. Svanstrom Elis, Ger. Offen. 2,125,018 (09 Dec. 1971); Chem. Abstr., 76, 35734 (1972).

8) E.D. Storms, "The Refractory Carbides", Academic Press, New York and London (1967) p. 1-17.

9) “JANAF 熱化学デー夕集” 堀越研究所 (1965-8) No. 16.

10) J. Hojo, T. Oku and A. Kato, J. Less-Common Metals, 59, 85-95 (1978).

11）王利信幸, 加藤昭夫, 窐協, 84, 409-11 (1976).

\title{
The Formation of Single Phase $\mathrm{Si}-\mathrm{Al}-\mathrm{O}-\mathrm{N}$ Ceramies
}

\author{
Mamoru MITOMO, Nobuyuki KURAMOTO*, \\ Masayuki TSUTSUMI and Hiroshige SUZUKI** \\ National Institute for Researches in Inorganic Materials, Niihari-gun 300-31
* Tokuyama Soda Co., Ltd., Tokuyama-shi 745
** Research Laboratory for Nuclear Reactors, Tokyo Institute of Technology,
Meguro-ku 152
}

The formation of single phase $\beta$-sialon was investigated in the system $\mathrm{Si}_{3} \mathrm{~N}_{4}-\mathrm{AlN}-\mathrm{Al}_{2} \mathrm{O}_{3}$ using hot pressing at $1750^{\circ} \mathrm{C}$ under $200 \mathrm{~kg} / \mathrm{cm}^{2}$. The starting powder mixture was $z=1,2$, 3 , and 4 in $\mathrm{Si}_{6-z} \mathrm{Al}_{z} \mathrm{O}_{z} \mathrm{~N}_{8-z}$ and it was in the range of solid solubility of $\mathrm{AlN} \cdot \mathrm{Al}_{2} \mathrm{O}_{3}$ into $\mathrm{Si}_{3} \mathrm{~N}_{4}$. The contamination by alumina during ball milling, the amount of $\mathrm{SiO}_{2}$ and $\mathrm{Al}_{2} \mathrm{O}_{3}$ on $\mathrm{Si}_{3} \mathrm{~N}_{4}$ and AIN powder as surface layer was considered to adjust the composition into restricted value.

Single phase $\beta$-sialon with very little amount of grain boundary phase, if any; was obtained in the composition $z=2$. A sialon with $z=1$ was incomplete in densification. Sialons with $z=3$ and 4 were pore free, but the reaction to form sialon was incomplete and a small amount of unreacted material was detected by density measurement and chemical etching by diluted mixed solution of $\mathrm{HF}$ and $\mathrm{HNO}_{3}$.

The process included in $\beta$-sialon formation was inferred to be, (1) the formation of $15 \mathrm{R}$ sialon, $\mathrm{x}$-phase and $\beta$-sialon with $z=2.3 \sim 2.5$ at lower temperature than $1600^{\circ} \mathrm{C}$, (2) Steep densification at higher temperature than $1600^{\circ} \mathrm{C}$ by liquid phase sintering with $\mathrm{X}$-phase as a "transient" liquid, (3) The approaching of $z$ value of $\beta$-sialon into predicted value as final stage.

[Received March 23, 1978]

\section{Si-Al-0-N セラミックス単相の合成}

\author{
三友 護・倉元信行*・堤 正幸・鈴木弘茂**

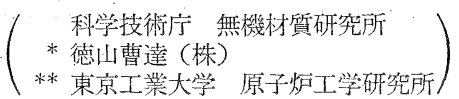

$\mathrm{Si}_{3} \mathrm{~N}_{4}-\mathrm{AlN}-\mathrm{Al}_{2} \mathrm{O}_{3}$ 系を用いて， $\beta$-sialon 単相の合成をホットプレスにより，1750 $\mathrm{C}, 200 \mathrm{~kg} / \mathrm{cm}^{2}$ の条件で行った。原料泣， $\mathrm{Si}_{6-z} \mathrm{Al}_{z} \mathrm{O}_{z} \mathrm{~N}_{8-z}$ に扔いて $z=1,2,3,4$ 亿なるよう粉末を混合して周い た。これは $\mathrm{AlN} \cdot \mathrm{Al}_{2} \mathrm{O}_{3}$ の $\mathrm{Si}_{3} \mathrm{~N}_{4}$ への固溶範团内である。

ボールミルによるアルミナの混入, $\mathrm{Si}_{3} \mathrm{~N}_{4}, \mathrm{AlN}$ 表面の酸化層である $\mathrm{SiO}_{2}, \mathrm{Al}_{2} \mathrm{O}_{3}$ を考慮し，混 合後各成分が計算量になるよう調合した。

$z=2$ の組成では, 単相で極めて粒界相の少ない焼結体が得られた。 $z=1$ で注収縮が不完全であ 